\title{
EFEKTIVITAS PERMAINAN GELAS ANGKA PADA KEMAMPUAN MEMBILANG ANGKA 1-10 ANAK USIA DINI
}

\author{
Arisna Wahyuni \\ Fakultas Tarbiyah dan Keguruan,Universitas Islam Negeri Antasari Banjarmasin \\ Email : arisnawahyuni.app@gmail.com
}

Wahyuni, Arisna.(2020)._Efektivitas Permainan Gelas Angka Pada Kemampuan Membilang Angka 1-10 Anak Usia Dini. Judul Artikel. Jurnal Pelita PAUD, 4(2), 161-167. doi: https://doi.org/10.33222/pelitapaud.v4i1.884

\begin{abstract}
Abstrak: Penelitian ini bertujuan untuk dapat memperoleh gambaran mengenai bagaimana efektivitas membilang angka 1-10 melalui metode permainan gelas angka pada anak kelompok A di TK Tunas Mekar Banjarmasin. Penelitian ini menggunakan metode eksperimen semu (quasi experimental design) dengan desain Nonequivalent Control Group Design . Sampel penelitian adalah kelompok A1 yang menggunakan permainan angka pada membilang 1-10 dan kelompok A2 tanpa menggunakan permainan gelas angka pada membilang angka. Teknik pengumpulan data yang digunakan adalah tes, wawancara, observasi dan dokumentasi. Hasil penelitian menunjukkan bahwa hasil belajar di kelas Eksperimen memilik nilai rata-rata sebesar 76,41 dan di kelas Kontrol memiliki nilai rata-rata sebesar 65,47 dengan selisih antara dua kelompok sebesar 10,47, yang berarti bahwa ada terjadinya peningkatan di kelas ekseperimen ketika menggunakan metode permainan gelas angka, maka penggunaan metode permainan gelas angka efektif digunakan pada kemampuan membilang angka 1-10 anak usia dini kelompok A di TK Tunas Mekar Banjarmasin.

Kata Kunci: Kemampuan Membilang, Permainan Gelas Angka

Abstract: This study aims to be able to get a picture of how the effectiveness of numerating numbers 1-10 through the method of playing glass numbers in group A children in Tunas Mekar Kindergarten Banjarmasin. This research uses quasi-experimental method (quasi experimental design) with Nonequivalent Control Group Design. The research sample is group Al that uses numbers on numbers 1-10 and group A2 without numbers playing on numbers. Data collection techniques used were tests, interviews, observations and documentation. The results showed that the learning outcomes in the Experiment class had an average value of 76.41 and in the Control class had an average value of 65.47 with a difference between the two groups of 10.47, which means that there was an increase in the experimental class when using the number glass game method, then the use of the glass number game method is effectively used in the ability to number 1-10 children in group A in Tunas Mekar Kindergarten Banjarmasin.
\end{abstract}

Keywords: Numerical ability, Number Glass game 


\section{PENDAHULUAN}

Usia dini atau pra sekolah adalah usia yang efektif untuk mengembangkan berbagai potensi yang dimiliki anak-anak. Proses pembelajaran pendidikan anak usia dini dan bukanlah proses belajar mengajar yang di selenggarakan di sekolah seperti biasanya, akan tetapi adalah sebagai tempat untuk bermain anak, mulai dari mengenal orang lain dan tempat dia untuk berkreasi. Taman kanak-kanak adalah salah satu bentuk pendidikan prasekolah yang bertujuan untuk membantu pertumbuhan dan perkembangan jasmani dan rohani peserta didik di luar lingkungan keluarga sebelum memasuki pendidikan dasar. Usaha ini di lakukan supaya peserta didik usia 4-6 tahun lebih siap mengikuti pendidikan selanjutnya. Sebagaimana terdapat dalam Garis-Garis Program Kegiatan Belajar Taman Kanak-Kanak (GBPKB TK 1994) bahwa Taman KanakKanak didirikan sebagai usaha mengembangkan seluruh segi kepribadian dan pendidikan sekolah. (Masitoh, 2005: 01)

Pada saat ini berbagai pihak menginginkan agar anak menguasai konsep dan keterampilan matematika semakin gencar, hal ini mendorong beberapa lembaga pendididkan anak usia dini untuk mengajarkan pengetahuan matematika secara sporadis dan radikal. Orang tua bahkan guru tidak menitikberatkan pembelajaran pada proses yang terjadi namun mereka lebih melihat pada hasil yang dicapai oleh anak.

Dalam pengenalan konsep membilang tidak terlepas dari pengenalan konsep tentang angkaangka. Pengenalan konsep angka melibatkan pemikiran tentang beberapa jumlah suatu benda atau beberapa banyak benda. Pengenalan konsep angka ini pada akhirnya akan memberikan bekal awal kepada anak untuk mempelajari berhitung dan operasi penjumlahan. Pada dasarnya anak sudah mempunyai kemampuan dasar matematika secara formal. Hal ini di tunjukkan dengan minat anak untuk mengetahui sesuatu yang baru di sekitar anak.

Ciri-ciri kemampuan berhitung atau membilang pada anak usia TK adalah anak bisa memahami dan mengenal bilangan dengan lancar dan baik dan anak mampu mengenal bilangan dengan benda yang sesuai dengan bilangannya. Kegiatan pembelajaran membilang yang di lakukan pada anak kelompok A menurut buku pedoman pembelajaran Bidang Kognitif antara lain: a. Membilang banyak benda 1-10 b. Membilang /menyebut urutan bilangan 1-10. c. Membilang dengan menunjuk benda 9 mengenal konsep bilangan dengan benda-benda) sampai 10 d. Menunjuk urutan benda untuk bilangan 1-10 e. Membuat urutan bilangan 1-10 dengan benda f. Menunjuk lambang bilangan 1-10 g. Meniru lambang bilangan 1-10 h. Menghubugkan /memasangkan lambang bilangan dengan bendabenda sampai 10 (Depdiknas, 2007:10).

Mengenal dan Menulis angka merupakan kemampuan yang dimiliki anak untuk mengetahui angka 1-10 atau lebih dan mengingat dari masing-masing simbol tersebut. Pada mulanya untuk mengenal angka anak diperkenalkan dahulu dengan simbol untuk angka yang kemudian dihubungkan untuk diperkenalkan dahulu dengan symbol untuk angka yang kemudian dihubungkan untuk menulis angka. Dapat dilakukan dengan guru atau orang tua, caranya yaitu dengan memperlihatkan beberapa gambar kemudian anak diminta untuk menulis jumlah gambar tersebut dengan angka (Coupley, 2007:55).

Berdasarkan observasi awal di TK Tunas Mekar, sebagian anak masih kesulitan untuk membilang angka 1-10. Hal ini karena anak belum banyak mengenal angka, sehingga dalam mengerjakan tugas dari guru, anak masih mengalami kesulitan. Misalnya dalam mengerjakan tugas mencontoh angka masih banyak yang salah, dalam menghubungkan lambang bilangan dengan benda, dalam menulis angka masih terbalik. Dalam pemberian stimulasi membilang pada anak, guru hanya menggunakan Lembar Kerja Anak (LKA), misalnya dalam membilang angka 1-10, sehingga anak menjadi bosan dan tidak tertarik untuk mengikuti kegiatan kegiatan belajar. Hal tersebut disebabkan Karena metode dan media yang di gunakan kurang menarik dan kurang menyenangkan. 
Sebenarnya membilang dapat diajarkan pada anak-anak dengan cara yang sangat mereka sukai, yaitu bermain. Atau dengan menggunakan alat peraga atau media yang menyenangkan dan membuat anak semakain tertarik untuk belajar membilang 1-10.“Anda tidak bisa memisahkan anak dari permainan dan memaksanya untuk belajar berhitung, misalnya, tanpa alat bantu permainan sama sekali. Justru ini aka mematikan kreativitas dan kemampun otaknya untuk belajar (Cahyo, 2011:11)

Metode dalam pembelajaran harus sangat diperhatikan. Pembelajaran harus bersifat menyenangkan dan tidak membuat peserta didik cepat tertekan atau bosan terhadap pembelajaran, begitu juga dengan pendidikan anak usia dini salah satu metode yang di terapkan dalam pendidikan anak usia dini yaitu dengan bermain, karena pada umumnya sangat menikmati permainan dan akan terus melakukannya di manapun mereka memiliki kesempatan. Dalam mengaplikasikan pembelajaran yang menyenangkan di perlukan kreativitas guru agar pembelajaran tersebut bersifat menyenangkan salah satu caranya nya yaitu dengan bermain.

Melalui bermain anak secara tidak langsung dia akan menambah pengetahunnya. Dalam kegitan belajar mengajar tidak hanya menitikberatkan dengan hasil yang di capai oleh anak akan tetapi lebih menitikberatkan terhadap proses pembelajaran tersebut. Bermain adalah suatu kegiatan yang dilakukan dengan menggunakan alat atau dengan tidak menggunakan alat, yang memberikan kesenangan maupun mengembangkan imajinasi anak. Jika kita benarbenar memahaminya maka pemahaman tersebut berdampak positif pada cara kita membantu proses belajar anak (Agung, 2013: 01).

Permainan dengan gelas angka merupakan salah satu teknik yang dapat diterapkan untuk kemampuan kognitif anak. Oleh karena itu alat permainan edukatif sangat perlu dalam peningkatan kegiatan belajar mengajar seperti halnya dalam bentuk permainan gelas angka. Gelas angka yang digunakan dalam permaian merupakan gelas yang terbuat dari bahan plastik agar aman bagi anak kemudian gelas tersebut dicat dengan bebagai macam warna dan bertulisan dengan angka 1-10. Metode bermain gelas angka adalah suatu cara mengefektifkan komunikasi dan interaksi antara guru dan peserta didik dalam proses pendidikan dan pengajaran. Gelas angka sebagai media pembelajaran dengan unsur permainan dapat memberikan rangsangan pada anakanak untuk terlibat aktif dalam kegiatan proses pembelajaran.

Berdasarkan permasalahan yang terjadi di TK Tunas Mekar, maka saya tertarik untuk meneliti bermain dengan menggunakan gelas angka sebagai salah satu cara mengenal konsep bilangan anak dan dapat memperbaiki kondisi pembelajaran yang terjadi di TK Tunas Mekar

\section{METODE PENELITIAN}

\section{Jenis Penelitian}

Jenis penelitian yaitu penelitian kuantitatif dengan pendekatan penelitian ini menggunakan metode kuasi eksperimen (quasi experimental research) dengan bentuk desain nonequivalent control group design. Pada penelitian ini terdapat dua kelompok yang di gunakan untuk penelitian, satu kelompok untuk eksperimen ( yang diberi perlakuan) dan satu kelompok lagi untuk kelompok kontrol ( yang tidak di beri perlakuan) (Sugiyono, 2011:116).

Jenis penelitian yang di gunakan adalah penelitian lapangan (field research), yaitu penelitiaan yang di lakukan dengan terjun langsung ke lapangan untuk meneliti efektifitas permainan gelas angka dalam pembelajaran membilang angka 1 sampai 10 pada anak usia dini. Teknik pengumpulan data yaitu dengan Tes, observasi, wawancara dan dokumentasi.

\section{Waktu dan Tempat Penelitian}

Waktu pelaksanaan penelitian yaitu pada bulan Februari- April 2018, yaitu pada tahun pelajaran 2017/2018. Penelitian ini diksanakan di TK Tunas Mekar Banjarmasin Kalimantan Selatan.

\section{Subjek Penelitian}

Subjek dalam penelitian ini adalah seluruh peserta didik yaitu 32 orang kelompok A TK 
Tunas Mekar Banjarmasin. Yang terdiri dari kelas A1 17 orang dengan 10 orang laki-laki dan 7 Perempuan dan kelas A2 15 orang dengan 9 orang laki-laki dan 6 orang perempuan.

\section{Prosedur Penelitian}

Penelitian ini merupakan penelitian kuanitatif dengan pendekatan penelitian menggunakan metode kuasi eksperimen (quasi experimental research) dengan bentuk desain nonequivalent control group design. Kelompok eksperimen dibagi jadi tiga tahap yaitu Pretest, Treatment dan Postest sedangkan kelompok control hanya 2 tahap yaitu Pretest dan Postest.

\begin{tabular}{|lll|r}
\hline O1 & X & O2 & bar \\
1. \\
O3 & O4 & in \\
\hline
\end{tabular}

Model Sugiono

Prosedur penelitian eksperimen ada beberapa tahap yaitu, tahap persiapan, tahap pelaksanaan (Pretest, penggunaan permainan gelas angka dalam penelitian, posttest) penelitian, tahap pengolahan dan analisis data dan menyimpulkan hasil penelitian.

\section{Teknik Pengumpulan Data}

Teknik pengumpulan data dalam penelitian ini adalah

1. Tes

Tes ialah seperangkat rangsangan (stimulasi) yang diberikan kepada seseorang dengan maksud untuk mendapat jawaban yang dapat dijadikan dasar bagi penetapan skor angka (Margono, 2014:170). Tes dalam penelitian ini dilakukan pada awal pertemuan (pretes) dan akhir pertemuan yaitu (postest). Tes yang digunakan untuk pengambilan data adalah sesuai dengan indikator yang dikembangkan.

2. Observasi

Observasi diartikan sebagai pengamatan dan pencatatan secara sistematik terhadap gejala yang tampak pada objek penelitian (Margono, 2014:158)
Observasi ini dilakukan untuk mengetahui keadaan peseta didik yang akan diteliti, gedung dan lingkungan sekolah serta sarana dan prasarana sekolah.

3. Dokumentasi

Dokumentasi adalah untuk mengumpulkan data-data selama melakukan pembelajaran mengenal angka 1-10 dengan menggunakan permainan gelas angka dan arsip-arsip sekolah yang dibutuhkan untuk melengkapi data maka diperlukannya dokumentasi.

4. Wawancara

Teknik pengumpulan data pada saat melakukan studi pendahuluan untuk menemukan permasalahan yang harus diteliti dan ingin mengetahui hal-hal yang lebih mendalam (Sugiyono, 2011: 194) Teknik ini digunakan untuk mengumpulkan data, melengkapi data yang diperoleh dari peneliti dari teknik observasi dan dokumentasi.

Instrumen yang akan digunakan dalam penelitian ini melewati pengembangan, dan pemberian skor terhadap instrument. Instrument yang digunakan yaitu berbentuk permainan. Hasil kegiatan diukur melalui tes yang dilakukan sebanyak 2 kali, tes sebelum perlakuan (pretest) dan tes sesudah perlakuan (post-test). Tes yang diberikan sama, baik yang untuk sebelum maupun yang sesudah yang terdiri dari 9 soal yaitu berupa unjuk kerja. Setiap soal mempunyai 4 skor paling tinggi, sehingga skor maksimum adalah 36 .

\section{HASIL PENELITIAN DAN PEMBAHASAN}

Penelitian ini dilaksanakan di Taman Kanakkanak Tunas Mekar Banjarmasin. Taman Kanak-kanak Tunas Mekar Banjarmasin didirikan pada tanggal 20 April 1980 oleh Bapa H. Kasriansyah S.Pd. TK ini didirikan karena 
melihat kondisi padatnya penduduk di wilayah sekitar Sungai Lulut tersebut mengakibatkan tidak semua anak dapat bersekolah TK dikarenakan tempat yang TK yang lumayan jauh. Kepala sekolah TK Tunas Mekar Banjarmasin dari berdirinyatersebut sampai sekarang adalah Ibu Kamilah S.Pd.

Untuk mengetahui keamampuan awal maka dilakukannya Pretest dilakukan untuk mengetahui perkembangan membilang anak1-10 di kelompok kontrol dan kelas eksperimen. Distribusi jumlah siswa yang mengikuti tes pada kelompok kontrol ada 15 orang dan kelompok eksperimen ada 17 orang. Dengan diperolehnya data tersebut, peneliti perlu mengetahui nilai rata-rata kelas untuk memastikan bahwa responden di kedua kelas tersebut, baik responden di kelas eksperimen maupun di kelas kontrol memiliki kemampuan yang sama atau tidak jauh berbeda. Berikut ini adalah hasil data tersebut;

Tabel 1. Skor kemampuan awal peserta didik kelompok eksperimen

\begin{tabular}{ccccc}
\hline No & Kriteria Penilaian & Skor & F & $\%$ \\
\hline 1 & BSB & 100 & 0 & - \\
2 & BSH & 80 & 1 & 6 \\
3 & MB & 60 & 13 & 76,4 \\
4 & BB & $0-40$ & 3 & 17,6 \\
& Total & & 17 & 100 \\
\hline
\end{tabular}

Berdasarkan pada tabel di atas, dapat dilihat bahwa dari sampel 17 anak, hanya satu orang anak yang dapat mengenal angka, baik itu menghubungkan angka dengan benda atauapun mengenal angka secara acak. Kebanyakan anak hanya dapat menyebutkan angka akan tetapi menghubungkan angka dengan symbol angka atau pun benda dengan bantuan guru.Penelitian ini memiliki kemampuan awal dikelas control dengan rata-rata 51,27 dan kelompok eksperimen memiliki rata-rata kelas 54,12. Hal tersebut menunjukkan bahwa kedua kelompok pada TK Tunas Mekar Banjarmasin memiliki kemampuan rata-rata yang hampir sama. Dengan demikian, diharapkan penellitian eksperimen yang akan dilaksanakan benar-benar menunjukkan hasil yang valid.Pada tahap selanjutnya adalah dilakukannya treatmeant untuk kelompok eksperimen, yaitu dengan permainan gelas angka dalam proses pembelajaran. Adapun di kelompok control proses pembelajaran menegena angka dengan media LKS.

Data untuk tes akhir (postest) anak kelompok A1 dan A2 adalah nilai posttest. Posttest dilakukan untuk mengetahui tes akhir, setelah dilakukannya treatment untuk kelas eksperiemen, hasil tersebut dapat terlihat pada table berikut;

Tabel 2. Skor kemampuan akhir peserta didik kelompok eksperimen

\begin{tabular}{ccccc}
\hline No & Kriteria Penilaian & Skor & F & $\%$ \\
\hline 1 & BSB & 100 & 1 & 6 \\
2 & BSH & 80 & 14 & 82,3 \\
3 & MB & 60 & 2 & 11,7 \\
4 & BB & $0-40$ & - & - \\
& Total & & 17 & 100 \\
\hline
\end{tabular}

Berdasarkan tabel 2 diatas, menunjukkan bahwa terdapat adanya peningkatan dari tes sebelumnya sebelum dilakukannya treatment, yaitu sebanyak 14 peserta didik mulai dapat mengenal angka, menghubungkan angka dengan symbol angkan maupun dengan benda. Hasil rata-rata yang diperoleh kelompok kontrol yaitu 65,47, sedangkan kelompok eksperimen memiliki nilai rata-rata 76,41 , jadi selisih antara nilai keduanya sebesar 10,47.

Kemampuan awal dari kedua kelas tersebut tidak ada perbedaan yang signifikan, setelah salah satu kelas diberi perlakuan terjadi peningkatan hasil belajar yang sangat signifikan yaitu kelas eksperimen yang diberi perlakuan dengan menggunakan permainan gelas angka mendapat nilai yang lebih tinggi dibandingkan dengan kelas kontrol.

Kemampuan awal dikelas eksperimen sebelum diberi perlakuan yaitu sebesar 54,00 setelah diberi perlakuan membilang angka 1-10 dengan permainan gelas angka ada perubahan peningkatan menjadi 76,41. Selisih peningkatan hasil belajar dikelas eksperimen sebesar 22,41. 
Terjadi peningkatan hasil belajar yang sangat signifikan. Sedangkan kemampuan awal dikelas kontrol sebesar 51,27 dan hasil belajar di kelas kontrol sebesar 65,47. Tidak terjadi peningkatan yang sangat signifikan. Selisih peningkatan hasil belajar di kelas kontrol hanya sebesar 14,02\%. Selisih kedua hasil belajar antara kelas eksperimen dan kelas kontrol sebesar 08,39.

Berdasarkan pengujian dengan menggunakan uji T diketahui nilai signifikansinya adalah $0,001<$ 0.05 maka Ho ditolak dan Ha diterima yang berarti bahwa ada perbedaan hasil belajar yang signifikan antara kelompok eksperimen dengan kelompok kontrol. Nilai rata-rata dikelompok eksperimen sebelum diberi perlakuan yaitu 54,00 sedangkan setelah diberikan treatment dengan permainan gelas angka memiliki ratarata $76,41 \%$, terjadi peningkatan sebesar $22,41 \%$ - sejalan dengan penelitian terdahulu yaitu membilang angka 1-10 dengan menggunakan permainan pohon hitung, hasil penelitian tersebut menunjukkan bahwa terjadi peningkatan sebanyak 22,9\%. Sehingga dapat dikatakan bahwa pembelajaran dengan permainan gelas angka dinyatakan efektif digunakan pada kemampuan membilang angka 1-10 pada anak TK A. Dilihat dari rata-ratanya yang menunjukkan bahwa hasil belajar kelompok eksperimen lebih baik daripada kelompok kontrol. oleh sebab itu pengenalan angka kepada anak usia dini lebih efektif dialkukan dengan berbagai macam permainan salah satunya adalah permainan gelas angka.

\section{SIMPULAN}

Berdasarkan penelitian yang telah dilakukan dapat simpulkan bahwa hasil belajar dikelas eksperimen yang menggunakan permainan gelas angka pada kemampuan membilang anak 1-10 berada pada kualifikasi baik dengan nilai ratarata 76,41 .

Sedangkan hasil belajar dikelas kontrol yang tanpa menggunakan permainan gelas angka pada kemampuan membilang anak 1-10 berada pada kualifikasi kurang baik dibandingkan pembelajaran dikelas eksperimen dengan nilai rata-rata 65,47. Penggunaan permainan gelas angka pada kemampuan membilang angka 1-10 di TK A lebih efektif digunakan daripada pembelajaran dengan metode klasikal.

\section{DAFTAR PUSTAKA}

Agung, T. (2013) Permainan Kreatif dan Edukatif untuk Anak Usia Dini. Yogyakarta: Andi Offset.

Cahyo, A. N. (2011) Gudang Permainan Kreatif khusus Asah Otak Kiri Anak. Yogyakarta: Flasbooks.

Coupley, J. (2007) The Young Child and Mathematics. Washington DC: National for The Children the Education of young Children.

Depdiknas (2007) Pedoman Pembelajaran Bidang Pengembangan Kognitif di Taman Kanak-kanak. Jakarta.

Fitriyani. (2015) Meningkatkan Kemampuan Mengenal Angka 1-10 dengan Media Gambar Asosiatif di Kelompok B Tk Budi Rahayu. Jurnal Pendidikan. 6. 1-9

Hartati Sofia, 2005 Perkembangan Belajar pada Anak Usia Dini,Jakarta,Depdiknas

Issabela Hasania, Aniek Wirastania. (2017). Mengembangkan Kemampuan Mengenal Angka 1-10 Melalui Kartu Angka pada Taman Kanakkanak Kelompok A. Jurnal Wahana. 69 . 61-66

Margono (2014) Metode Penelitian Pendidikan. Jakarta: Rineka Cipta.

Masitoh (2005) Pendekatan Belajar Aktif Di Taman Kanak-Kanak. Jakarta.

Montolalu dkk, 2012, Bermain dan Permainan Anak, Tangerang Selatan,Universitas Terbuka

Sugiyono (2011a) Metode Penelitian kuantitatif, Kualitatif dan $R \& D$. Bandung: Alfabeta.

Sugiyono (2011b) Metode Penelitian Pendekatan Kuantitatif dan $R \& D$. Bandung: Alfabeta.

Sudarwati Umi. (2018) Peningkatan Kemampuan Membilang 1-20 Melalui Permainan Puzzle pada Anak Kelompok B di TK Tunas Rimba 1 Samarinda Tahun Pembelajaran 2016/2017. Jurnal Warna. 3 (1). 20-37

Syafitri, ockti dkk (2018) Peningkatan Kemampuan Mengenal Lambang Bilangan 1-10 Melalui Permainan Pohon Hitung pada Anak Usia 4-5 Tahun di BKB PAUD Harapan Bangsa. Jurnal Al-Azhar Indonesia Seri Humaniora. 4 (3). 193205

Triharso Agung, 2013 Permainan Kreatif dan Edukatif untuk Anak Usia Dini: (Yogyakarta;Andi Offset,)

Rahman Taopik dkk. (2017) Peningkatan Kemampuan Anak usia Dini Mengenal Konsep Bilangan Melalui Media Flashcard. Jurnal PAUD agapedia. 1 (1). 118-128

Reswita, wahyuni sri (2018) Efektivitas Media Pasir 
P ISSN 2548-6284 E ISSN 2615-0360

Arisna Wahyuni

Vol. 4 No. 2 Juni 2020

dalam Meningkatkan Kemampuan konsep Bilangan pada Anak Usia 5-6 Tahun di Tk Aisyiyah Bengkalis. Jurnal Lectura:Jurnal Pendidikan 9 (1). 43-51. 